Estonian Journal of Archaeology, 2005, 9, 1, 60-72

Sigita Mikšaitė

\title{
PRODUCTION OF CERAMICS OF NARVA CULTURE (RECONSTRUCTIONS BASED ON EXPERIMENTAL ARCHAEOLOGY)
}

\begin{abstract}
The pottery of Narva Culture was the first ceramics in the East Baltic Region. In the course of practical experiment, the questions related to the production technology of Neolithic pottery were resolved and studied in detail. That includes clay preparation, coil joining, ornamentation and firing. Vessels were made experimentally, giving an understanding of the archaic techniques and traditions of the Neolithic potters. Two ways for ceramics firing, namely field hearth and pile-fire have been tested.

Narva-tüüpi keraamika oli esimene keraamikaliik Ida-Baltikumis. Praktiliste eksperimentide käigus uuriti üksikasjalikult neoliitilise keraamika valmistamise tehnoloogiaga seotud küsimusi: savi ettevalmistamine, savilintide ühendamine, nõude kaunistamine ja põletamine. Savinõude eksperimentaalne valmistamine aitas mõista neoliitiliste pottseppade arhailisi tehnikaid ja traditsioone. Ühtlasi testiti kaht keraamika põletamise viisi: põletusaugus ja tuleriidal.
\end{abstract}

Sigita Mikšaitè, Lithuanian Institute of History, 5 Kražių st., LT-01108 Vilnius, Lithuania; pakrapstyk@yahoo.com

\section{Introduction}

In the East Baltic region where the cultures of hunters and fishermen lasted longer than in Central Europe, the appearance of ceramics is considered to be a very important feature indicating the beginning of the new Neolithic age. In Lithuanian, Latvian and Estonian historiography such an approach has been and still is dominating (Rimantiene 1996; Girininkas 1994; Kriiska 2001; Loze 2001; Brazaitis 2003). In Lithuania, the early start of the Neolithic is dated 5500/5300 cal. BC (Antanaitis-Jacobs \& Girininkas 2002). Latvian archaeologists start the Early Neolithic since $5500 \mathrm{cal}$. BC (Loze 2001), Estonia dates it $4900 \mathrm{cal}$. BC (Lang \& Kriiska 2001).

For the archaeologists investigating the Neolithic culture, forms of ceramics, mixtures and ornamentation served as the base for the cultural evolution schemes and reflect traditions of history. In their work researchers do not ignore questions related to the production and use of ceramics. However, these issues are often 
considered secondary. Therefore, it is indispensable to trace all the stages of the vessels' production process.

The aim of the described experiments within this research work was to reconstruct production technologies and traditions of Narva-type ceramics, to ascertain different ways of pottery molding and decoration of their surface using many different tools. We tried to look at ceramics production from a Neolithic potter's point of view and strove to perceive concrete traditions of the ceramics production. Pottery has been molded on the basis of the analogues from Šventoji 6th settlement, Daktariškès 5th settlement and Žemaitiškès 2nd settlement (Lithuania; Fig. 1).

\section{History of research}

There is quite a number of theoretical works classifying, summarizing and analyzing in detail the Neolithic ceramics. However, the research of archaeological ceramics and its production technology reconstructions have not attracted much

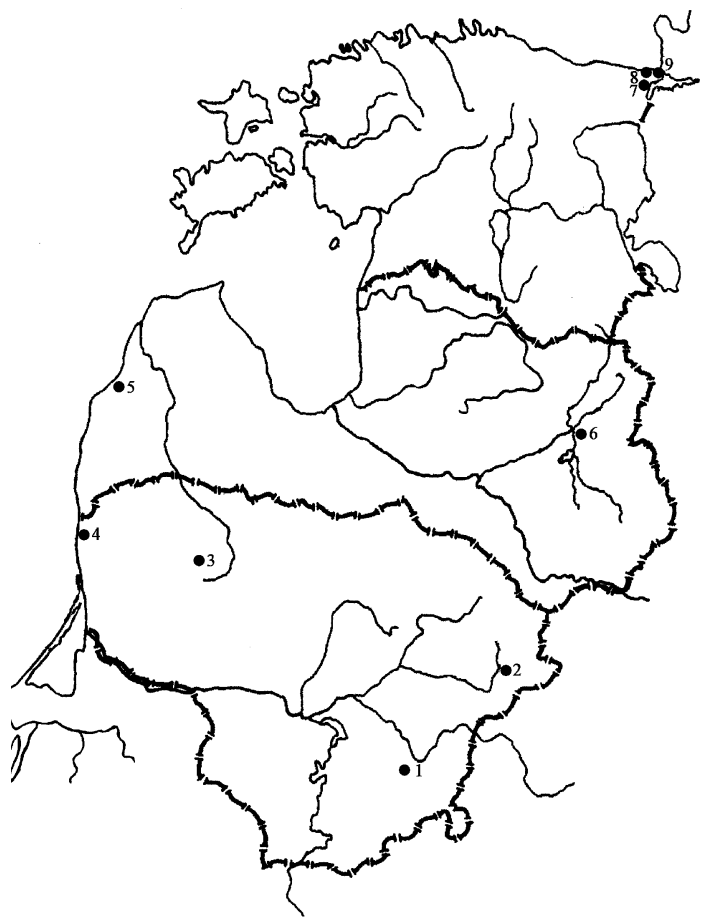

Fig. 1. Location of the sites mentioned in the paper. Lithuania: 1 Trakai, 2 Žemaitiškès 2, 3 Daktariškès 5, 4 Šventoji 6. Latvia: 5 Sārnate, 6 Piestina. Estonia: 7 Narva Joaoru, 8 Riigiküla, 9 Lommi III.

Joon 1. Artiklis käsitletud muististe asukoht. attention although the revival of the old technologies and traditions is a very important factor for the deepening knowledge about the pattern of life of previous generations.

The East Baltic archaeologists, Nina Gurina, Ilze Loze, Rimutè Rimantienè, Lucija Vankina who were the first to assess ceramics as reflector of cultural-ethnical processes, paid attention to such features as the importance of mixtures, molding techniques, firing temperature.

There are currently only a few researchers who reconstruct the Neolithic ceramics production process not only for their own pleasure but also for science and education. In Estonia, questions related to ceramics production were investigated in theory and practice by Aivar Kriiska (Kriiska et al. 1991; Kriiska 1996; Kalm et al. 1997). The article by Baiba Dumpe which appeared recently 
in Latvia raises problems related to ornamentation technology production of the Corded Ware (Dumpe 2003). In the research works Valdis Berziņš focuses on ceramics of a Narva-type Sārnate settlement in Latvia (Berziņš 1999; 2000; 2003). In Lithuania Džiugas Brazaitis carried out analysis of the Narva-type ceramics technology, morphology and ornamentation (Brazaitis 2002; 2003). However, so far there are no articles devoted to the reconstruction of Neolithic ceramics in the historiography of Lithuanian archaeology.

For already five years, the Vilnius Guild of Potters has been periodically organizing archaic ceramics camps in Trakai (Lithuania), in the courtyard of the Peninsula Castle. The researchers are engaged there in the research of scientific archaeological ceramics and reconstruction of the old technologies using an experimental method. Narva Culture ceramics was chosen to be the main topic for the 2004 summer camp. However, the summer camp was not limited to practical activity, theoretical questions also came into view and hypotheses were checked out.

\section{Sources and methods}

A sufficient base of theoretical knowledge was accumulated in the preparation stage for practical activities. First of all, it has thoroughly examined the original Narva Culture ceramics, i.e. many ceramics findings stored in the Lithuanian National Museum from Šventoji 6th settlement, Daktariškès 5th settlement and Žemaitiškès 2 nd settlement were analyzed. The level of the roast of fragments and their surface was evaluated in the review process. Professional potters were greatly surprised by the work of their predecessors - pieces of ceramics were very light but sufficiently strong and had survived perfectly. To avoid confusion between many forms and ornaments, the most characteristic and frequent vessel types and ornaments motifs were identified for reconstructions.

All possible material from different sources was collected. Theoretical knowledge related to the peculiarities of Narva-type ceramics, the pattern of life of Narva Culture people was taken into consideration based on the works performed by prominent cultural researchers Rimutė Rimantiené, Algirdas Girininkas, Ilze Loze and Lucija Vankina.

One should mention that the features of the pottery of Narva Culture in the East Baltic region differ. It can be divided into several local variants. The Narvatype pottery material from Lithuania will be the basis in this research.

\section{Presentation of material}

The principles of all Neolithic ceramics production can be divided into several main stages: 1) preparation of clay mass; 2) molding of a vessel; 3) ornamentation of surface; 4) drying and 5) firing. Each of these aspects received particular attention. 
Preparation of clay mass. The first step in pottery molding is the preparation of clay mass. Paste-making is the process by which raw materials such as clay, temper, and water are blended. It is very important to know how to prepare raw materials for use, how and in what proportions to mix them.

Since Narva Culture ceramics distinguishes from ceramics of other Neolithic cultures by its specific clay mass, the greatest attention was devoted to the clay mass while performing the experiment.

The first attempt was focused on the clay mass with crushed shells. This temper of clay mass is most characteristic of the pottery of Narva culture. Since most of the Neolithic settlements, particularly in Lithuania, were located close to water bodies (Brazaitis 2003), shells could be found in ceramics almost in every settlement.

Berziñš, having examined the mixture of shells in ceramics, states that before crushing, the shells used to be fired (Berziňš 2000). This thought has been fully approved by Dumpe, who carried out the reconstructions of Corded Ware (Dumpe 2003). In the process of the experiment, shells split easily into sufficiently small fragments and it does not require additional crushing by hand after they are burnt in the ember, put into the vessel and watered. Besides, cracked burnt shells do not cut hands. For the burning of shells by primitive conditions temperature must not be too high, otherwise the shells crumble to dust and are not suitable to be mixed in clay. However, if shells are not sufficiently burnt it is difficult to crush them.

Crushed shells in the clay mass are characteristic of several features. The first is that this kind of temper increases the durability of ceramics against technical and mechanical load (Berziňs 2000). However, this fact has not been thoroughly investigated. The second characteristic feature is their susceptibility to heat. A vessel with such a temper will crumble if burnt at too high temperature. Calcite $\left(\mathrm{CaCo}_{3}\right)$ starts to split at $650-750{ }^{\circ} \mathrm{C}$. When the vessel cools down, calcium oxide $(\mathrm{CaO})$ conjuncts with air humidity, generating calcium hydroxide $\left(\mathrm{Ca}(\mathrm{OH})_{2}\right)$, which is composed of bigger crystals. Expanding calcium can fissure walls of a vessel or crush it completely. Yet, this could be avoided by insuring that the burning temperature does not exceed $750-800{ }^{\circ} \mathrm{C}$ and some salt is mixed into the clay mass, for example, simple natrium chloride or forming clay mass with salty water. Without any doubt, shell mixture had an important role in providing durability of pots for boiling, and that in some cases it could compensate the low temperature of firing.

Other basic organic material, used as temper of Narva-type pottery, was plant remains. The use of this type of mixture is obvious from the lightness of the pots, the porosity of walls and the imprints visually observed in the breaks of chips. The hypotheses of chopped straws were rejected immediately after the first attempts. Many difficulties appeared while trying to chop them into small pieces and the fragments appeared too big for molding. Clay mass with crushed straws was not flexible and it was difficult to shape. No problems emerged with crushed 
hay or grass. Thin and tiny hay parts more or less distribute evenly when clay is molded.

It is considered that pots with plant mixture are more sensitive to heat, that is why a pot placed into fire becomes warm much quicker. Of course, due to the porosity of a vessel, water permeability increases. This is why the surface of vessels meant for cooking food and keeping liquids had to be covered by impermeable substance or other means used to ensure impermeability.

In the discussions about the variety of mixtures and their qualities, a hypothesis emerged concerning the use of horse dung as a temper. Some considerations on using other substances, such as bird manure can be found in literature (Лозе 1988). However, there are certain doubts since it is not clear how such amounts of it could be collected. Such doubts were not raised while discussing the dung of horse or other animal feeding on grass. The necessary amount of this kind of dung can be easily collected. Hay within manure is distributed evenly, and this is why clay mass is easily shaped if clay is kneaded with horse dung. Since digested hay becomes softer, clay mass is plastic and the molding becomes much easier. Pots burnt with dung mixture have a remarkable lightness.

After burning, the abrasion made in the new pottery was compared with that in the original Narva-type ceramic fragments (Fig. 2). Nevertheless, in order to approve or reject the hypothesis concerning this type of mixture used in Narva Culture ceramics, more research work has to be conducted. Thus, so far this question remains open.

Molding vessels. The goal of Trakai summer camp was to select a concrete archaeological sample and restore analogues which comply with the original parameters as much as possible (Fig. 3).

Before starting to mold pots with pointed bottom, which are characteristic of Narva Culture, there was a debate as to where the molding should start. If work starts from the spike, it will be difficult to hold the vessel. It had to be found out
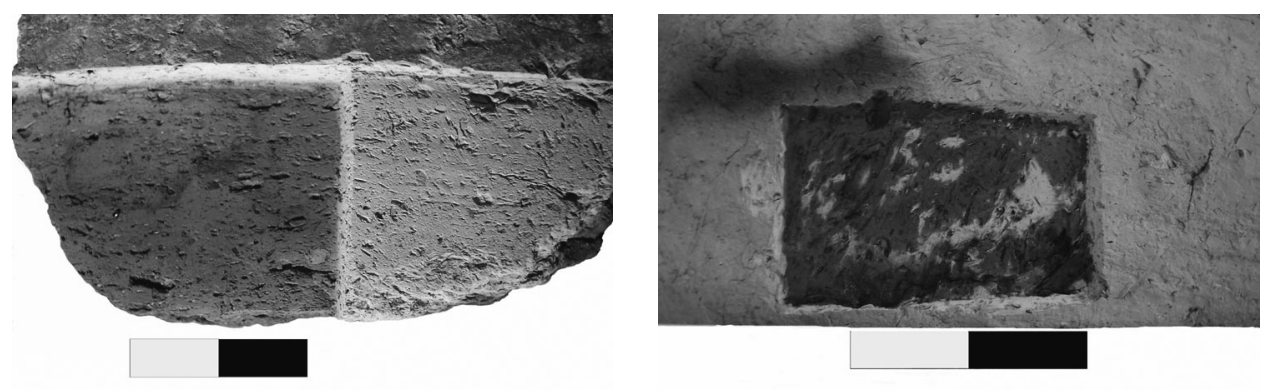

Fig. 2. Crosscut of the original Narva-type fragment (left) and newly burnt vessel with dung temper (right). In both fragments the imprints of burnt out organic mixture are visible. Photos by Dainius Strazdas.

Joon 2. Narva-tüüpi savinõu killu (vasakul) ja sõnnikuga segatud savist tehtud uue savinõu killu (paremal) läbilõige. Mõlemal katkel on näha välja põlenud orgaanilise lisandi jälgi. 

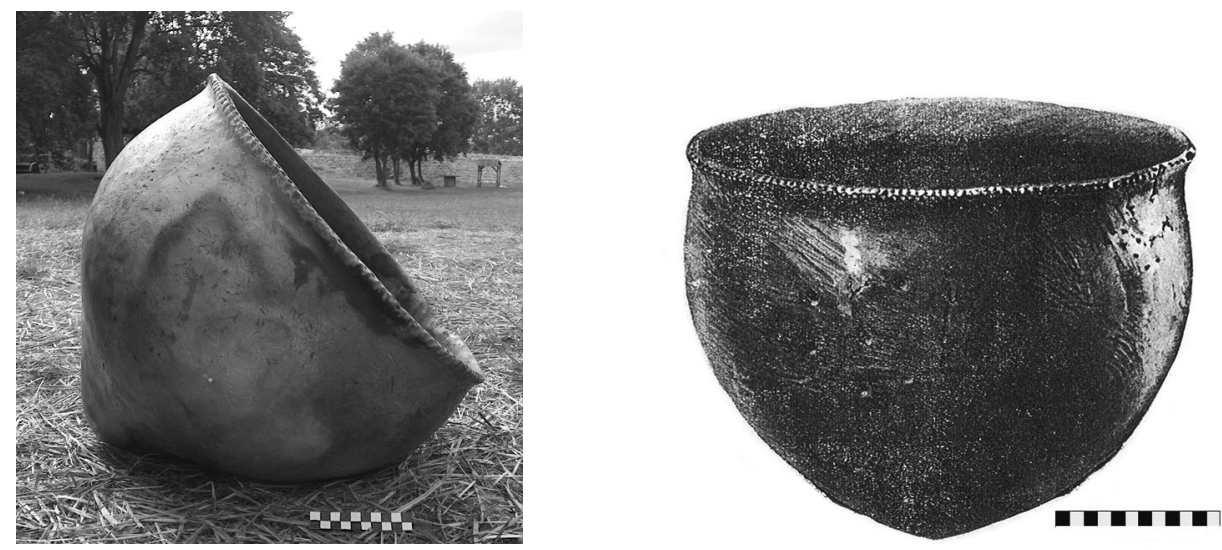

Fig. 3. The pot (analogue) burnt in field hearth in Trakai, Lithuania. The vessel was made in accordance with the photo and description of authentic example (Sārnate settlement, Latvia). Photos by author and from Vankina (1970).

Joon 3. Trakai (Leedu) põletusaugus põletatud savinõu, mis valmistati Sārnate asulakohast (Läti) leitud nõu foto ja kirjelduse järgi.

how to hold the vessel in the upright position and at the same time not damage its form. Many methods were analyzed, of which two appeared to be the most suitable: the molded vessel is placed into a pit with hay or into a ring which is made from clay. It should be sufficiently thick so that it would hold the growing weight of a pot. If the pot is molded from the mouth and continuously narrowing, it could be difficult to connect clay coils at the spike.

The form of vessels with pointed bottom most probably emerged because of its functionality. However, researchers have unanswered questions why such type of vessel was produced and used.

The East Baltic region researchers engaged in the Neolithic ceramics state in unison that the Neolithic vessels were molded from different clay coils, the conjunction methods of which have received lots of attention (Rimantiene 1979; Kriiska 1996; Berziņš 2000; Brazaitis 2002). There are two basic methods to join the clay coils together: U-type and N-type.

a) U-type. In the profile of the vessel wall, the line for the coil conjunction is seen as round: the rim of lower coil is convex, whereas the upper coil is concave.

b) N-type. In the profile of the vessel wall the line of both lower and upper coils thinned out into narrow edges in opposite directions.

It should be noted that different conjunction methods could be encountered in the same settlements.

When investigating Lubāna lowland (Latvia) settlements Loze identified a characteristic method for wall thinning. This technique was called "scoop and anvil", i.e. the walls, upheld from the outside, were whisked up from the inside of 
the vessel up to desirable thickness (Loze 1983). It seems that this method for thinning of the walls is used even now. By whisking it is possible not only to thin the walls of a vessel, but to shape the desirable form and smooth out roughness.

The other method for wall thinning is to scrape off the unnecessary thickness with a sharp tool. It became clear that this could be done with the help of a big scallop, flat stone with sharp rims or a polished wooden plate. After such scrap the walls retain an embossed shading (Brazaitis 2002).

Pottery with walls has evident advantages since such pots are lighter. Besides, they convey warmth better and increase resistance against repeated thermal impact (Berziņš 2000; Brazaitis 2003). In other cases, priority is given to vessels with thick walls: because of lower permeability of heat they can be used for keeping liquids and are resistant to mechanical load. Certainly, lower heat permeability has also a negative side if the content in the vessel has to stay warm for a longer time.

Ornamentation. Tools. Few basic ornament groups can be distinguished in Narva-type ceramics (Brazaitis 2003; Лозе 1988):

- first group refers to imprints. By the shape they can be distributed into several subgroups: bigger and smaller round pits, right-angled columns, grain form and triangle imprints (Iršėnas \& Butrimas 2002). In most Narva-type ceramics these elements are dominating;

- second group contains comb-like ornaments, made by a toothed ornamentation tool. In Lithuanian historiography this ornament is related to the Combed Ware Culture, though Estonian archaeologists do not agree with this assumption;

- third group refers to corded and textile imprints. Most often these ornaments are considered the result of making the surface even with a stick with a cord around it (Dumpe 2003). Knot imprints might be also ascribed to this group.

Since there are no tools for ornamentation in the archaeological material, one can only guess about them. However, it did not take long to find an answer. A simple wooden stick appeared to be the most convenient and universal tool for ornamentation. If an artisan wants to decorate the vessel by round pits, he just has to choose a stick with the desired thickness. Right-angled or triangle imprints can be made by adjusting its shape using a sharp tool. In order to make the tools last longer, they can be easily made of bone. A birch-bark suits well for the polishing of the surface of a vessel.

Firing. Unfortunately, the evidence about the hearths of the Neolithic potters is very poor. All researchers of Neolithic ceramics admit that pots were burnt in the open fire. Some of them call this method firing of the pit, others firing of the fireplace. All names are correct. However, "field hearth" seems to be the most appropriate for ceramicists (Strazdas 2004) (Fig. 4).

It is advisable to make the place for burning deep, so that pots burn in the pit. The edges of the pits have to be piled by stones of two or three layers since in the burning process they reflect heat. A few stones are placed on the pit bottom so that the heat which is generated between live coal and pot rises up. Earthenware is placed on them. Gaps are left for firewood. A gap is also left between the vessel 

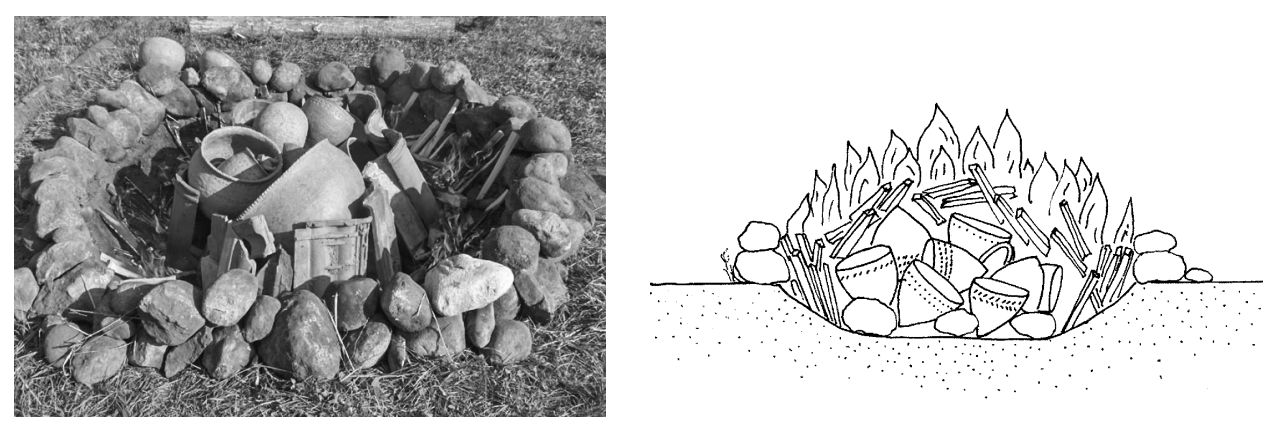

Fig. 4. Field hearth at the beginning of heating. The principle of firing of field hearth. Photo and picture by author.

Joon 4. Põletusauk põletamise algul. Paremal - põletusaugus põletamise põhimõte.

and the edges of the pit, which is filled with chopped firewood. It is important to maintain even heating, it takes two-three hours, and it must be made sure that the fire will not reach the pottery. After that, firewood is placed closer to the wares and the temperature is increased. It is important to know that the hearth becomes heated unevenly. The artifacts placed inside and at the bottom heat more slowly. The field hearth finishes heating by placing firewood between the articles and above them. At the end of burning the hearth is closed down. The diminishing fire is covered with some organic substance, e.g. sawdust, and sand is spread over them. The hearth is left to cool down.

It is easier to watch the sides of the artefacts and judge upon the temperature if the burning takes place in the dark. In the opinion of the potters who used this process, the temperature in the hearth could reach up to $850{ }^{\circ} \mathrm{C}$ in the upper side and $950-1000{ }^{\circ} \mathrm{C}$ at the bottom. However, this temperature is too high for the vessels molded with the shell mixture. The temperature should not reach beyond $750{ }^{\circ} \mathrm{C}$ if one wants shells kneaded with clay not to disintegrate and crack the vessel. After examining a few fragments of Narva-type ceramics from Narva Joaoru, Lommi III and Riigiküla (Estonia), it was established that their firing temperatures most probably exceeded $700{ }^{\circ} \mathrm{C}$ (Kriiska 1996). Research conducted by Vankina showed that vessels produced in the Sārnate settlement (Latvia) were burnt at temperature not exceeding $600{ }^{\circ} \mathrm{C}$ (Ванкина 1970). Ceramics research of the Piestina settlement which is located in the Eastern part of Latvia showed that the average burning temperature even reached $400-500^{\circ} \mathrm{C}$ (Zagorskis 1973).

Examining the old Narva-type potsherds, it was noticed that their colour is predominantly grey, dark grey or black. One should naturally keep in mind that the colour of pottery depends on the contact with oxygen when burning and the composition of the soil of the cultural layer. However, some potsherds clearly reveal that colours of inside and outside differ. It could be explained by the not very high temperature of firing. 
Thus, it was proved that the old ceramics were not burnt fully but only well dried. This is due to low temperatures. The strength of potsherds can be compared with a piece of chalk. At first sight, this fragment is hard. However, if one scrapes it by a sharp tool, it easily crumbles.

One more method of burning archaic ceramics has been tested in Trakai. Potters called it "anthill" (Fig. 5) (Strazdas 2004). It is no primitive fire as it at first might appear. It is piled carefully and according to a special system. Two or three layers of large pieces of woods are placed at the bottom. The vessels are put on them. Fine firewood is inserted into the gaps. All this construction is evenly covered by a layer of straw which is coated by tempered clay. The moistened straw burns slower and longer, heating slowly the vessels inside. In the lowest part of the cone on the ground, a mouth is cut to burn the fire inside the "anthill". At the top of the cone, there is a small hole, a chimney. While burning, it is important that the fire does not go out and that it is not too strong. After four-five hours the fire gradually goes down to the main piles of firewood, above which the wares are placed. The temperature is increased by closed "anthill" walls. The "anthills" are left to cool down when the firewood stops burning.

A similar burning method was described by Berziņš and Kriiska (Berziņš 2000; Kriiska 1991; 1993), although they describe the burning process with the open fire flame, i.e. neither clay nor straws are used for covering pots and wood.

Based on ethnographic data, this method of burning came from South China. The old Romans used some of the "anthill" burning principles. They used to place clay and straws on the lower kiln part (Strazdas 2004).
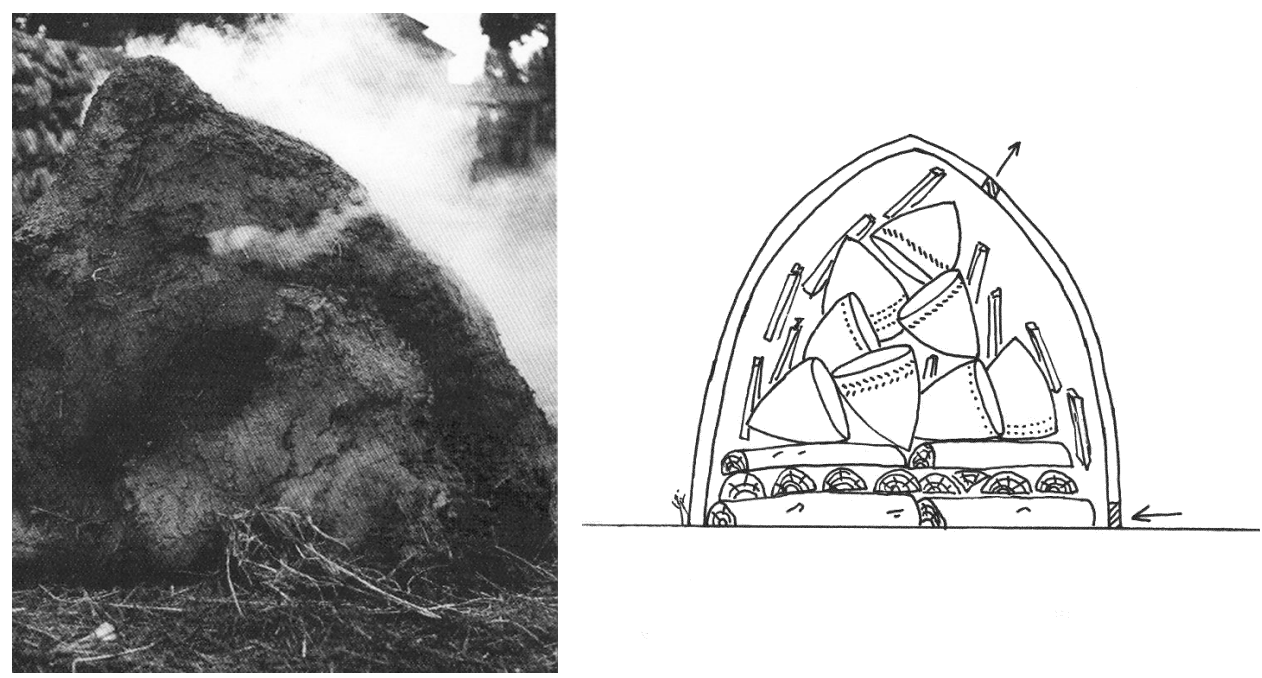

Fig. 5. "Anthill" after two hours of heating. On the right - the principle of firing of pile fire. Photo by Audrius Kacelavičius, picture by author.

Joon 5. Põletusriit pärast kaht tundi põletamist. Paremal - riidas põletamise põhimõte. 
Water permeability. Permeability of ceramics to water decreases when ceramics burns at high temperature. However, the Narva-type ceramics was burnt at very low temperature, which is why after the burning process water saturates through the vessel walls. It has been observed that the more organic mixtures in the clay mass, the easier and quicker does water saturate through the vessel walls. Due to this, it has been necessary to cover the surface of vessels meant for keeping liquids and preparing food with water-resistant substance or use other methods to stop the permeability.

One of the packing methods is covering the vessel surface with resin. Most often it was applied to the vessels when still warm after burning (Berziňš 2000). Certainly, this method cannot be applied to vessels meant for cooking food. Resin can only be used for covering the inside part of the vessel. If used on the outside, this material burns out. One more method to prevent permeation is to boil food in the vessel which then gets burnt to the walls of vessel and fills the pores in them. However, this method causes some uncertainty as the thick layer of burnt substance inside the vessel appears not only because of the burnt product, but also because of the burning surface layer while using the vessel. Also it is possible that people did not try to clean the vessels on purpose, realizing its benefit for the reduction of permeability.

\section{Summary and conclusions}

The molding techniques of archaic ceramics can be learnt fast but much more experience is needed to achieve the required thickness of the walls or a desirable form of a vessel.

The Trakai camp had the aim of restoring an analogue which would be as close as possible to the original. Concrete archaeological samples were selected, which were then restored according to all available parameters.

The preparation of clay mass is the basic stage in the ceramics production. The resistance of vessels in fire depends on the clay and the mixtures. It is important to remember that vessels molded from clay and mixed with shells are not very heat-resistant. When they burn the temperature should not exceed $750{ }^{\circ} \mathrm{C}$. The camp discussed using horse manure in the preparation of clay mass. Unfortunately, after many experiments this question is still undecided.

The forms of Narva-type ceramics are not of great variety. One more question remains unanswered which relates to the reasons why the Neolithic people produced and used pointed-bottom vessels.

The vessels of the Neolithic age were molded from different clay coils by connecting them in two ways, called U-type and N-type. From the first sight, there is a big variety of the Narva-type ceramic ornaments. After more thorough analysis, however, they can be divided into only a few groups: imprints, comblike ornaments and corded textile imprints. Natural tools were selected for ornamentation: sticks, shells, birch bark. 
The burning of vessels is the most difficult and decisive stage and requires a lot of patience and experience. Two ceramics burning methods were tested in the Trakai camp: field hearth, where vessels are put in a pit, loaded with firewood and heated continuously, and the "anthill" method where vessels and firewood are placed in an orderly heap and covered by tempered clay. Referring to low burning temperature $\left(400-750{ }^{\circ} \mathrm{C}\right)$, different colours in the sherds, it is possible to confirm that the Narva-type ceramics used to be dried but not burnt.

After burning, it is necessary to ensure that vessels are resistant to liquids. This is assumed to be achieved in two ways: by covering the surface of a vessel by resin and boiling food in a vessel, which clings to the walls and fills in the pores.

Characteristic forms of vessels, their size, shells and plant mixtures, ornaments motives transferred from generation to generation, as well as molding and burning technique used also nowadays means the development of pottery traditions. The Neolithic potters achieved an outstanding professional level. Big vessels produced by them even if they were burnt at low temperature were sufficiently strong and could survive in the open fire. Ceramics is an important source for researching material and spiritual culture. If questions related to ceramics production and technologies of usage become priority, new knowledge would make it possible to look at culture from another point of view.

\section{Acknowledgements}

The author is very grateful to the Vilnius Guild of Potters for the possibility to participate in the organization of the camp of archaic ceramics.

\section{References}

Antanaitis-Jacobs, I. \& Girininkas, A. 2002. Periodization and chronology of the Neolithic in Lithuania. - Archaeologia Baltica, 5, 9-39.

Berziņš, V. 1999. Sārnates neolīta apmetnes māla bḷodiṇas. - Latvijas vēstures institūta žurnals, 4, $17-26$.

Berziņš, V. 2000. Keramikas darināšana un lietošana Sārnatē. - Arheologiija un etnogrāfija, XX, 43-59.

Berziņš, V. 2003. Sārnates apmetnes keramikas klasifikācija un statistiska analīze. - Arheolog̣ija un etnogrāfija, XXI, 53-73.

Brazaitis, D. 2002. Narviškos keramikos stiliai Rytų Lietuvoje. - Lietuvos archeologija, 23, 51-72.

Brazaitis, D. 2003. Rytų Lietuva neolito ir bronzos amžiaus sandūroje. Daktaro disertacija. Vilnius.

Dumpe, B. 2003. Jauni atzinumi par neolīta klājošās auklas keramiku. - Arheoloǵija un etnogrāfija, XXI, 110-117.

Girininkas, A. 1994. Baltų kultūros ištakos. Vilnius.

Iršėnas, M. \& Butrimas, A. 2002. Daktariškès 5-osios gyvenvietès keramikos su organinès kilmès priemaišomis ornamentika. - Lietuvos archeologija, 19, 125-138. 
Kalm, V., Kriiska, A. \& Aruväli, J. 1997. Mineralogical analysis applied in provenance studies of Estonian Neolithic pottery. - Proceedings of the Estonian Academy of Sciences. Geology, 46: 1, $17-33$.

Kriiska, A., Mägi, T. \& Peets, J. 1991. Neues in der Experimentalarchäologie. - TATÜ, 40: 4, 400-412.

Kriiska, A. 1993. Saviaeg savijalgadel. - Horisont, 7, 4-9.

Kriiska, A. 1996. The Neolithic pottery manufacturing technique of the lower course of the Narva river. - Coastal Estonia. Recent Advances in Environmental and Cultural History. (PACT, 51.) Rixensart, 373-384.

Kriiska, A. 2001. Stone Age Settlement and Economic Processes in the Estonian Coastal Area and Islands. Academic dissertation. Helsinki. http://ethesis.helsinki.fi/julkaisut/hum/kultt/vk/kriiska.

Lang, V. \& Kriiska, A. 2001. Eesti esiaja periodiseering ja kronoloogia. - EAA, 5: 2, 83-109.

Loze, I. 1983. Jauni materiāli par agro neolītu Lubāna lidzenumā. - Latvijas PSR zinātņu akadēmijas vēstis, 6 (431), 88-100.

Loze, I. 2001. Neolīts. - Latvijas senāka vesture: 9. g.t. pr.Kr. - 1200. g. Rīga, 74-115.

Rimantienè, R. 1979. Šventoji. Narvos kultūros gyvenvietès. Vilnius.

Rimantienė, R. 1996. Akmens amžius Lietuvoje. Vilnius.

Strazdas, D. 2004. Senosios keramikos technologijos. Rekonstrukcijų epizodai. - Senosios keramikos pédomis. Vilnius, 6-14.

Zagorskis, F. 1973. Agrais neolìta laikmets Latvijas austrumdaḷā. - Latvijas PSR zinātņu akadēmijas vēstis, 4 (309), 56-69.

Ванкина Л. В. 1970. Торфяниковая стоянка Сарнате. Рига.

Лозе И. А. 1988. Поселения каменного века Лубанской низины. Мезолит, ранний и средний неолит. Рига.

\section{Sigita Mikšaitè}

\section{NARVA KULTUURI KERAAMIKA VALMISTAMINE (EKSPERIMENTAALARHEOLOOGILISED REKONSTRUKTSIOONID)}

\section{Resümee}

Vilniuse Keraamikute Gildi korraldatud arhailise keraamika valmistamise laager Trakais (Leedu) on seadnud endale eesmärgiks teha savinõusid, mis sarnanevad originaalsetega nii palju kui võimalik. Selleks on välja valitud konkreetsed arheoloogilised leiud ning püütud rekonstrueerida neid kõigi võimalike parameetrite alusel.

Neoliitilise keraamika valmistamise põhietapid on järgmised: savimassi ettevalmistamine, nõu vormimine, pinna ornamentimine, nõu kuivatamine ja põletamine. Kõiki neid etappe püüti projekti käigus üksikasjalikult tundma õppida.

Savimassi ettevalmistamine on keraamika tegemisel üks olulisemaid etappe. Savinõu vastupidavus põletamisel sõltub otseselt savi segamisest ja sellele lisatud materjali omadustest. Keraamikalaagris püstitati tööhüpotees hobusesõnniku kasutamisest savimassi ettevalmistamisel, kuid hoolimata paljudest katsetest jäi küsimus endiselt lahtiseks. 
Neoliitiliste savinõude valmistamisel kasutati erinevaid savilinte, mida võidi ühendada kahel eri viisil: U- ja N-tüüpi ühendusega. Narva-tüüpi keraamika ornamentika sisaldas mitmeid elemente: lohud, kammivajutused ja nöörtekstiili pressingud. Kõige sagedasemateks ornamendimotiivideks olid siiski väikesed ümarad või nelinurksed lohud, mille tegemiseks kasutati looduses leiduvaid vahendeid: pulgakesi, teokarpe, kasetohutükke.

Kõige raskem ja vastutusrikkam töö oli keraamika põletamine, mis nõuab rohkesti kogemusi ja oskusi. Trakai laagris katsetati kaht põletusviisi. Esimesel juhul asetati savinõud põletusauku, mis täideti puudega ja süüdati seejärel põlema. Teisel juhul laoti savinõud ja puud korrapärasesse riita, mis kaeti tambitud savikihiga. Narva-tüüpi savinõude värvuse põhjal otsustades võib arvata, et neid põletati üsna madalal temperatuuril $\left(400-750{ }^{\circ} \mathrm{C}\right)$; seda võib nimetada pigem kuivatamiseks kui põletamiseks.

Pärast põletamist oli vajalik katta nõu pinnad vettpidava vahendiga või kasutada muid võimalusi niiskusläbivuse peatamiseks. Arvatakse, et selle tegemiseks kasutati neoliitikumis kaht meetodit: nõupinnad kaeti kas vaiguga või keedeti nõu sees toitu, kuni see kõrbes nõu pinda sisse ja kattis poorid.

Olles tundma õppinud Narva-tüüpi keraamika valmistamistehnoloogia detaile, võib väita, et neoliitilised pottsepad olid saavutanud väljapaistva professionaalse taseme. 